Check for updates

Cite this: RSC Adv., 2019, 9, 12928

\title{
Gram-scale carbasugar synthesis via intramolecular seleno-Michael/aldol reaction $\uparrow$
}

\author{
Piotr Banachowicz (D) and Szymon Buda (D)* \\ Carbasugars represent an important category of natural products possessing a broad spectrum of biological \\ activities. Lots of effort has been done to develop gram scale synthesis. We are presenting a new approach \\ to gram scale synthesis of the carbasugar skeleton via intramolecular seleno-Michael/aldol reaction. The \\ proposed strategy gave gram amounts of 6 -hydroxy shikimic ester in a tandem process in $36 \%$ overall \\ yield starting from D-lyxose. We have attempted to demonstrate the synthetic utility of 6- \\ hydroxyshikimic acid derivatives by covering the important synthetic modifications and related \\ applications, namely synthesis of protected (-)-gabosine E, (-)-MK7606, (-)-valienamine and finally \\ unprotected methyl (-)-shikimate.
}

Received 15th March 2019

Accepted 17th April 2019

DOI: $10.1039 / \mathrm{c} 9 \mathrm{ra0} 2002 \mathrm{k}$

rsc.li/rsc-advances

high, prices are low and chemistry of carbohydrates is well known. An application of monosaccharides to carbohydrate mimetic synthesis seems to be a natural choice. ${ }^{12}$ General synthesis of carbasugars moieties is employing Grubbs cross metathesis reaction, ${ }^{13-16}$ aldol-type cyclization, ${ }^{17,18}$ Corey-Fuchs reaction ${ }^{19}$ and others. ${ }^{3}$ Total synthesis of gabosines has been recently reviewed by Mac and co-workers. ${ }^{20}$

Our proposal of shikimic-type esters synthesis and their reduced analogues is based on modification of 6-hydroxyshikimic ester ${ }^{21,22}$ obtained via intramolecular seleno-Michael/ aldol reaction from D-lyxose (Scheme 1).

saccharides suggests that they are likely to bind and inhibit same protein targets. The advantage of carbasugar containing compounds is the lack of a glycosidic linkage resulting in the increased stability toward enzymatic degradation. ${ }^{5,6}$ For example, synthetic nucleotide analogues containing thiosugar or carbasugars have been reported to be glycosyltransferase inhibitors. $^{7-9}$ The mechanism of glycosidase inhibition has been studied and several carba-analogues, such as Sergliflozin$\mathrm{A}^{\mathbf{1 0}}$ or SL0101, ${ }^{11}$ have been introduced (Fig. 1). Growing interest of carbasugar use is limited due to their low availability from natural sources.

General strategies to obtain carbapyranoses can be broadly classified into two groups: (i) synthetic methods that employ non-carbohydrates as starting materials and (ii) protocols that utilize carbohydrates as precursors. Multi gram synthesis of carbasugar fragments is still challenging and extremely important.

Carbohydrates, especially monosaccharides, are excellent starting material for total synthesis of various natural and valuable synthetic compounds. Their availability is usually very

Faculty of Chemistry, Jagiellonian University, Gronostajowa 2, 30-387 Krakow, Poland.E-mail: szym.buda@gmail.com

$\dagger$ Electronic supplementary information (ESI) available. See DOI: $10.1039 / \mathrm{c} 9 \mathrm{ra02002k}$

\section{Results and discussion}

First, we prepared oxo- $\alpha, \beta$-unsaturated ester (8) according to the literature method in multi-gram scale. ${ }^{23}$ Mixture of 2,3,4-tri-Obenzyl-D-lyxopyranoses (6) have been refluxed with excess of ylide over $12 \mathrm{~h}$ yielding mixture of $E / Z$ isomers of 7 . Alcohol 7 has been oxidized to corresponding aldehyde 8 using Swern oxidation in $78 \%$ yield. Compound $\mathbf{8}$ has been subjected to intramolecular seleno-Michael/aldol reaction with consecutive oxidation-elimination process to afford a mixture of 6-hydroxyshikimic esters (5) in 56\% yield for $7 \mathrm{~h}$ (Scheme 2). ${ }^{24}$

After short optimization, multistep tandem reaction gave the carbocyclic products $(\mathbf{6 S})-\mathbf{5}$ and $(\mathbf{6 R})-5$ in $76 \%$ yield over 3 steps

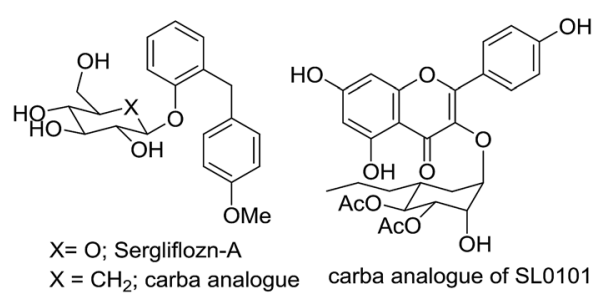

Fig. 1 Active carbasugars containing compounds. 
<smiles>O=C(O)C1=CC(O)[C@H](O)[C@H](O)C1</smiles><smiles>O=C1C(CO)=CC(O)[C@H](O)[C@H]1O</smiles>

(-)-Shikimic acid (1)

(-)-Gabosine E (2)<smiles>C=C=CC(=O)OC1C(=O)C=C(Cc2ccccc2)C(O)[C@@H]1OCc1ccccc1</smiles>

ethyl 6-hydroxyshikimate (5)

Scheme 1 General strategy of cyclitols synthesis

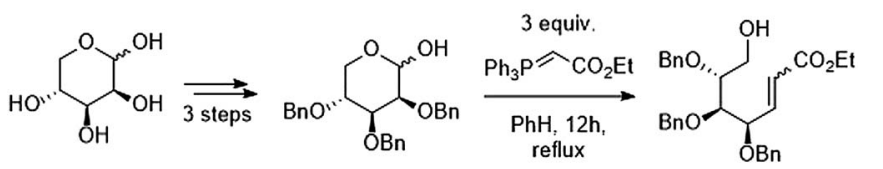
D-lyxose $6.77 \%$ $7,77 \%(E / Z=0.5: 1)$ \begin{tabular}{c|c} 
DCM, 1h, & DMSO, \\
$-78{ }^{\circ} \mathrm{C}$ & $(\mathrm{COCl})_{2}$
\end{tabular}<smiles>CCOC(=O)C1=CC(OCc2ccccc2)C(O)[C@H](Cc2ccccc2)C1O</smiles>
(6S)-5 anti, $42 \%$

(6R)-5 syn, $14 \%$

$8,78 \%$

Scheme 2 Synthesis of key intermediate.

as an $1: 0.33$ mixture of axial and equatorial alcohol (Table 1). The $6 S / R$-isomers of 5 have been separated easily by column chromatography (Experimental section). Having established the optimized conditions for the cyclic core synthesis, further functionalization has been achieved.

\section{Synthesis of protected $(-)$-valienamine}

The $6 S$-hydroxyshikimic ester $(\mathbf{6 S})-\mathbf{5}$ has been transformed to non-natural valienamine derivative $(\mathbf{1 1})$ with known protocol in 27\% yield over 3 steps. ${ }^{16,24}$ Exposure of 10 to chlorosulfonyl isocyanate in DCM afforded the desired product (11) in 51\% yield. Minor product has been assigned by NMR analysis as C3epimer of (-)-valienamine (12) (Scheme 3).

Table 1 Scale optimization ${ }^{a}$

\begin{tabular}{|c|c|c|c|c|}
\hline Entry & Scale & Conditions & Yield & Anti/syn \\
\hline 1 & $174 \mathrm{mg}(0.35 \mathrm{mmol})$ & $-20^{\circ} \mathrm{C}(6 \mathrm{~h})$ & $56 \%$ & 10.32 \\
\hline 2 & $\begin{array}{l}1080 \mathrm{mg}(2.21 \\
\mathrm{mmol})\end{array}$ & $-78{ }^{\circ} \mathrm{C}(30 \mathrm{~min})$ & $76 \%$ & 10.32 \\
\hline 3 & $\begin{array}{l}5600 \mathrm{mg} \\
(11.45 \mathrm{mmol})\end{array}$ & $-78{ }^{\circ} \mathrm{C}(30 \mathrm{~min})$ & $76 \%$ & 10.33 \\
\hline
\end{tabular}

${ }^{a}$ Reaction conditions: THF, 1.2 equiv. $n$-BuSeLi to RT (30 min), 10 equiv. $\mathrm{H}_{2} \mathrm{O}_{2}, 5$ equiv. py, $50{ }^{\circ} \mathrm{C}(1 \mathrm{~h})$.
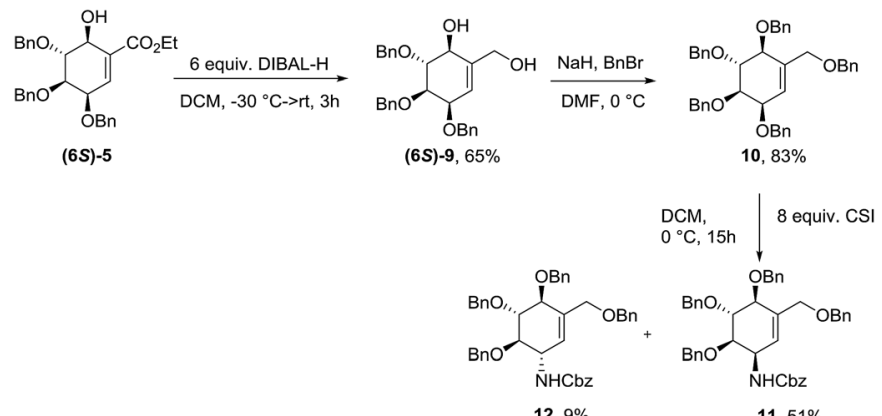

Scheme 3 Synthesis of protected (-)-valienamine.

\section{Synthesis of protected (-)-MK7607}

Syn-isomer of compound $\mathbf{5}$ was transformed to partially protect unnatural (-)-MK7607. Simple reduction with DIBAL-H gave compound (6R)-9 in 33\% yield which is surprising to the result obtained for $6 S$-isomer (65\%) at the same conditions (Scheme 4).

\section{Synthesis of protected (-)-gabosine $\mathbf{E}$}

Starting from diastereomeric mixture of 5, ester fragment has been reduced in the presence of DIBAL-H to give diol 9 in $48 \%$ yield. Selective protection of primary hydroxyl group gave mixture of isomers 13 in 64\% yield. Oxidation with Dess-Martin reagent in DCM to unsaturated ketone (14) and consecutive silyl ether deprotection gave 2,3,4-tri-O-benzylated (-)-gabosine E (15) in $84 \%$ yield in two steps (Scheme 5).

\section{Synthesis of methyl (-)-shikimate}

(-)-Shikimic acid is an important metabolite in plants and microorganisms. This compound can be isolated from the Japanese star anise or synthetized starting from chiral and achiral substrates. Recently, Candeias et al. ${ }^{25}$ summarized

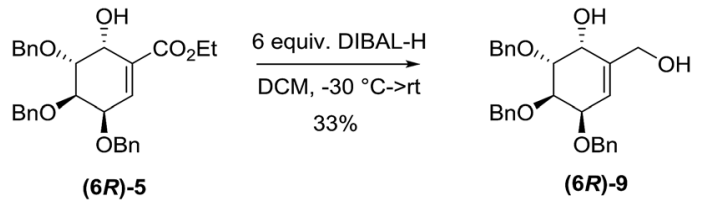

Scheme 4 Synthesis of unnatural (-)-MK7607.

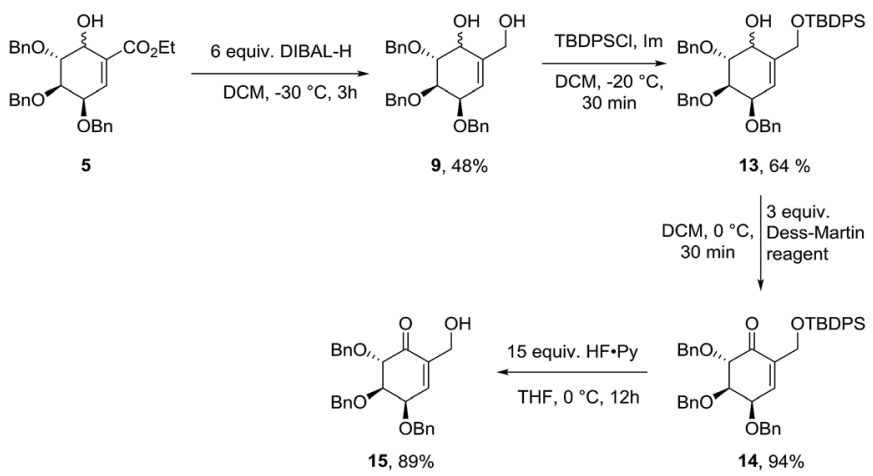

Scheme 5 Synthesis of (-)-gabosine E derivative. 
Table 2 Deoxygenation of 6-hydroxyshikimic acid

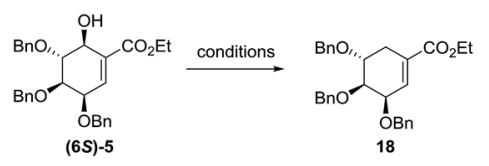

\begin{tabular}{lll}
\hline Entry & Conditions & Yield \\
\hline 1 & $\mathrm{Et}_{3} \mathrm{SiH}, \mathrm{BF}_{3} \cdot \mathrm{Et}_{2} \mathrm{O}, \mathrm{DCM}, \mathrm{rt}, 1 \mathrm{~h}$ & $\mathrm{nr}$ \\
2 & $\mathrm{EtO}_{3} \mathrm{SiH}, \mathrm{TFA}, \mathrm{DCM}, \mathrm{rt}, \mathrm{up}$ to $24 \mathrm{~h}$ & $\mathrm{nr}$ \\
3 & $\mathrm{Tf}_{2} \mathrm{O}, \mathrm{DCM}-40{ }^{\circ} \mathrm{C}, 30 \mathrm{~min}, 0{ }^{\circ} \mathrm{C}$, & $\mathrm{nr}$ \\
& $30 \mathrm{~min}$ then $\mathrm{NaBH}_{4}, \mathrm{EtOH}$ & \\
4 & $\mathrm{NaH}, \mathrm{Im}, 0{ }^{\circ} \mathrm{C}, 30 \mathrm{~min}, \mathrm{THF}$ then $\mathrm{CS}_{2}$, & $\mathrm{nr}^{a}$ \\
& $30 \mathrm{~min}, \mathrm{rt}$, then MeI, $30 \mathrm{~min}, \mathrm{rt}, 50{ }^{\circ} \mathrm{C}, 1 \mathrm{~h}$ & \\
&
\end{tabular}
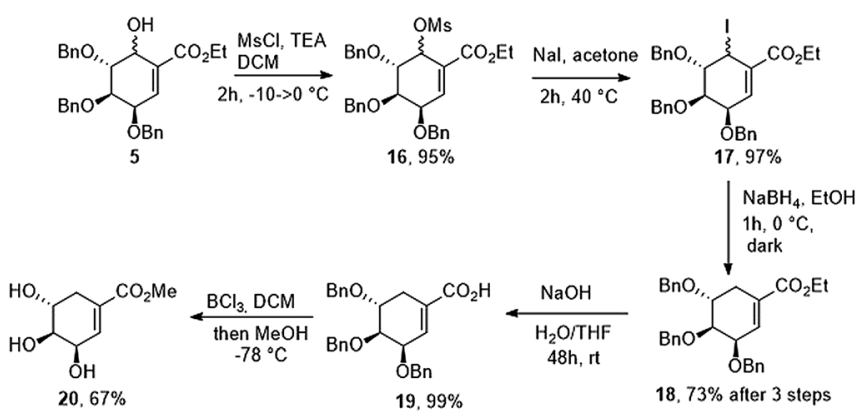

Scheme 6 Synthesis of methyl (-)-shikimate.

known methods of (-)-shikimic acid synthesis. Starting from diastereomeric mixture of alcohols 5 several deoxygenation methods have been tested (Table 2).

Finally, alcohol 5 was converted to mesylate 16. Unfortunately, all of our attempts to displace the mesylate group with hydride reagents resulted only in the 1,4-displacement. We decided to change mesylate group to iodide (17) and we found that halogenated compound (17) is unstable in the presence of light. In the end, reduction of iodide crude mixture carried out in the dark gave ethyl (-)-tri-O-benzylshikimate (18) in $2 \mathrm{~h}$ in $73 \%$ yield over 3 steps. Ethyl ester has been removed under basic conditions to give (-)-3,4,5tri-O-benzylshikimic acid in quantitative yield. Exposure of 19 to $\mathrm{BCl}_{3}$ gave methyl (-)-shikimate (20) in $67 \%$ yield (Scheme 6).

\section{Conclusions}

In summary, we have developed simple methods that provide a rapid entry into the synthesis of a series of shikimate ester and shikimate analogues, including (-)-gabosine $\mathrm{E}$ and (-)-MK7606. Our synthesis of 6-hydroxy shikimates from D-lyxose has been efficiently achieved in six steps with a $35 \%$ overall yield. The strategies described take place through short, highyield reaction sequences. Partial protection of D-lyxose derivative enable access to selective modification of hydroxyl groups. Deoxygenation of 6-hydroxyshikimic ester gave methyl $(-)$-shikimate in $49 \%$ yield total.

\section{Experimental}

\section{General experimental procedures}

All starting materials and reagents were purchased from commercial sources and used without purification. Reactions were controlled using TLC on silica [alu-plates $(0.2 \mathrm{~mm})]$. Plates were visualized with UV light $(254 \mathrm{~nm})$ and by treatment with: aqueous cerium(rv) sulfate solution with molybdic and sulfuric acid followed by heating. All organic solutions were dried over anhydrous magnesium sulfate. Reaction products were purified by column chromatography using silica gel 60 (240-400 mesh). Optical rotations were measured at room temperature with a digital polarimeter. $\mathrm{CDCl}_{3}, \mathrm{D}_{2} \mathrm{O}, \mathrm{CD}_{3} \mathrm{OD}$ were used as NMR solvents. ${ }^{1} \mathrm{H}$ spectra were recorded with 600 and $300 \mathrm{MHz}$, and referenced relative to: $\mathrm{CDCl}_{3}$ - solvent residual peak $(\delta=7.26$ ppm); $\mathrm{D}_{2} \mathrm{O}$ - solvent residual peak $(\delta=4.79 \mathrm{ppm}) ; \mathrm{CD}_{3} \mathrm{OD}-$ solvent residual peak $(\delta=3.31 \mathrm{ppm})$. Data are reported as follows: chemical shift in parts per million (ppm), multiplicity ( $\mathrm{s}$ $=$ singlet, $\mathrm{d}=$ doublet, $\mathrm{t}=$ triplet, $\mathrm{dd}=$ doublet of doublets, $\mathrm{ddd}$ $=$ doublet of doublet of doublets, dddd $=$ doublet of doublet of doublet of doublets, $\mathrm{m}=$ multiplet), coupling constants (in hertz) and integration. ${ }^{13} \mathrm{C}$ NMR spectra were measured at 150 and $75 \mathrm{MHz}$ with complete proton decoupling. Chemical shifts were reported in ppm from the residual solvent as an internal standard: $\mathrm{CDCl}_{3}(\delta=77.16 \mathrm{ppm}) ; \mathrm{CD}_{3} \mathrm{OD}(\delta=49.00 \mathrm{ppm})$. High-resolution mass spectra were acquired using ESI-TOF method.

\section{2,3,4-Tri-O-benzyl-D-lyxopyranose (6)}

To methanolic solution of $1 \% \mathrm{HCl}(50 \mathrm{~mL})$ (prepared by dissolving $1 \mathrm{~mL} \mathrm{SOCl}_{2}$ in anhydrous methanol) D-lyxose (5.0 g, 33.3 $\mathrm{mmol}$ ) was added in one portion and resulting mixture was refluxed for $5 \mathrm{~h}$ under argon (reaction was monitored by TLC $\mathrm{CH}_{2} \mathrm{Cl}_{2} / \mathrm{MeOH} 2: 1$ ). The reaction mixture was allowed to cool to room temperature, neutralized by addition of solid $\mathrm{NaHCO}_{3}$ and concentrated under reduced pressure. The residue was dissolved in EtOH $(40 \mathrm{~mL})$ and concentrated to the half of the original volume, toluene $(25 \mathrm{~mL})$ was added and the mixture was concentrated to dryness. The residue crude mixture oil was used without further purification in the next step. The viscous oil from the previous step was dissolved in anhydrous DMF (50 $\mathrm{mL})$ and anhydrous THF $(50 \mathrm{~mL})$ and in 5 portion was added to $60 \% \mathrm{NaH}$ suspension in mineral oil $(6.8 \mathrm{~g}, 170 \mathrm{mmol})$ cooled to $0{ }^{\circ} \mathrm{C}$. After hydrogen evolution was complete the mixture was treated with $\mathrm{BnBr}(14.8 \mathrm{~mL}, 122 \mathrm{mmol})$ and stirred for $30 \mathrm{~min}$ in $0{ }^{\circ} \mathrm{C}$ and then $12 \mathrm{~h}$ in room temperature. The reaction mixture was carefully quenched with cold, $10 \%$ aqueous solution of $\mathrm{NH}_{4} \mathrm{Cl}(30 \mathrm{~mL})$ followed by addition of water $(75 \mathrm{~mL})$. The aqueous layer was extracted with EtOAc $(3 \times 50 \mathrm{~mL})$ and combined organic layers were washed with water $(2 \times 60 \mathrm{~mL})$ and brine $(50 \mathrm{~mL})$, then dried over anhydrous $\mathrm{MgSO}_{4}$ and concentrated under reduced pressure. Crude mixture of $\mathrm{D}^{-}$ 
lyxosides from previous step was heated under reflux for $15 \mathrm{~h}$ with $1 \mathrm{M} \mathrm{H}_{2} \mathrm{SO}_{4}(42 \mathrm{~mL})$, AcOH (48 mL) and 1,4-dioxane (44 mL). Mixture was cooled to rt and extracted with EtOAc $(2 \times 100 \mathrm{~mL})$. Organic phase was washed twice with water $(2 \times 50 \mathrm{~mL})$ and brine $(50 \mathrm{~mL})$ and dried over anhydrous $\mathrm{MgSO}_{4}$. After solvent evaporation residue was purified by column chromatography (Hex/EtOAc $2: 1$ to $3: 2$ ) to afford mixture of anomers of 2,3,4tri-O-benzyl-D-lyxopyranose as a colorless oil (10.97 g, $26.1 \mathrm{mmol}$, yield $=78 \%) .{ }^{1} \mathrm{H}$ and ${ }^{13} \mathrm{C}$ spectra were compared with lit. ${ }^{23}$

\section{Ethyl (4R,5R,6R)-4,5,6-tri-O-benzyl-7-hydroxyhept-2-enoate (7)}

To a solution of $6(10.0 \mathrm{~g}, 23.8 \mathrm{mmol})$ in anhydrous benzene $(200 \mathrm{~mL})$, ethyl (triphenylphosphoranylidene)acetate $(16.5 \mathrm{~g}$, $47.6 \mathrm{mmol}$ ) was added in one portion and mixture was heated to reflux for $8 \mathrm{~h}$. After that time next portion of ethyl (triphenylphosphoranylidene)acetate $(8.3 \mathrm{~g}, 23.8 \mathrm{mmol})$ was added and heating to reflux was continued for next $4 \mathrm{~h}$. Reaction mixture was cooled to room temperature and benzene was evaporated under reduced pressure. Most of triphenylphosphine oxide was precipitated from the mixture of $\mathrm{Et}_{2} \mathrm{O} / \mathrm{Hex} 7: 3$ and filtered by suction. Solvent was removed under reduced pressure and crude product was purified by column chromatography (Hex/ EtOAc $3: 1$ to $7: 3)$ to afford product as a colorless syrup (8.95 g, $18.2 \mathrm{mmol}, 77 \%, Z / E=1: 0.6) .{ }^{1} \mathrm{H}$ NMR $(600 \mathrm{MHz}$, $\left.\mathrm{CDCl}_{3}\right) \delta 7.36-7.26(\mathrm{~m}, 24 \mathrm{H}), 7.06(\mathrm{dd}, J=15.9,6.6 \mathrm{~Hz}, 1 \mathrm{H}), 6.40$ $(\mathrm{dd}, J=11.8,9.1 \mathrm{~Hz}, 0.6 \mathrm{H}), 6.14(\mathrm{dd}, J=15.8,0.9 \mathrm{~Hz}, 0.6 \mathrm{H}), 5.97$ $(\mathrm{dd}, J=11.8,0.8 \mathrm{~Hz}, 1 \mathrm{H}), 5.48-5.44(\mathrm{~m}, 1 \mathrm{H}), 4.80(\mathrm{~d}, J=11.5 \mathrm{~Hz}$, $1 \mathrm{H}), 4.68(\mathrm{~d}, J=11.8 \mathrm{~Hz}, 1.6 \mathrm{H}), 4.63(\mathrm{~d}, J=11.6 \mathrm{~Hz}, 1 \mathrm{H}), 4.60(\mathrm{~d}$, $J=5.1 \mathrm{~Hz}, 1 \mathrm{H}), 4.59-4.57(\mathrm{~m}, \mathrm{~Hz}, 2.4 \mathrm{H}), 4.51(\mathrm{~d}, J=11.6 \mathrm{~Hz}$, $1 \mathrm{H}), 4.47$ (d, $J=11.7 \mathrm{~Hz}, 1 \mathrm{H}), 4.30$ (d, $J=11.5 \mathrm{~Hz}, 0.6 \mathrm{H}), 4.28-$ $4.25(\mathrm{~m}, 0.6 \mathrm{H}), 4.22(\mathrm{q}, J=7.1 \mathrm{~Hz}, 1.2 \mathrm{H}), 4.17(\mathrm{qd}, J=7.1,0.9 \mathrm{~Hz}$, $2 \mathrm{H}), 3.89(\mathrm{dd}, J=6.0,3.7 \mathrm{~Hz}, 1 \mathrm{H}), 3.80-3.68(\mathrm{~m}, 3.8 \mathrm{H}), 3.66-3.61$ $(\mathrm{m}, 1.6 \mathrm{H}), 1.31(\mathrm{t}, J=7.1 \mathrm{~Hz}, 1.8 \mathrm{H}), 1.27(\mathrm{t}, J=7.1 \mathrm{~Hz}, 3 \mathrm{H}) ;{ }^{13} \mathrm{C}$ NMR $\left(150 \mathrm{MHz}, \mathrm{CDCl}_{3}\right) \delta 166.0,146.5,145.4,138.6,138.5,138.3$, 138.2 , 137.8, 137.7, 128.6, 128.6, 128.5, 128.5, 128.4, 128.4, $128.2,128.1,128.0,127.9,127.9,127.8,127.8,127.8,127.8$, 127.7, 124.0, 122.5, 81.4, 81.1, 80.2, 79.2, 78.6, 74.8, 74.6, 73.7, 73.1, 73.1, 71.6, 71.5, 61.9, 61.9, 60.7, 60.5, 14.4, 14.3; HRMS (ESI): calcd for $\mathrm{C}_{30} \mathrm{H}_{34} \mathrm{O}_{6} \mathrm{Na}[\mathrm{M}+\mathrm{Na}]^{+}$513.2248, found 513.2258.

\section{Ethyl $(4 R, 5 R, 6 R)-4,5,6$-tri-O-benzyl-7-oxohept-2-enoate (8)}

A solution of oxalyl chloride $(3.91 \mathrm{~mL}, 45.7 \mathrm{mmol})$ in anhydrous methylene chloride $(200 \mathrm{~mL})$ was cooled to $-78{ }^{\circ} \mathrm{C}$, after that DMSO (6.49 mL, $91.4 \mathrm{mmol})$ was added dropwise and stirred for $30 \mathrm{~min}$. The $7(7.47 \mathrm{~g}, 15.2 \mathrm{mmol})$ was dissolved in anhydrous methylene chloride $(100 \mathrm{~mL})$, slowly added to oxidative mixture and kept in $-78{ }^{\circ} \mathrm{C}$ for $30 \mathrm{~min}$. The triethylamine $(19.26 \mathrm{~mL}$, $137.0 \mathrm{mmol}$ ) was slowly added and stirring was continued for next $30 \mathrm{~min}$, after that reaction mixture was allowed to slowly warm to $0{ }^{\circ} \mathrm{C}$. The reaction was quenched with addition of sat. $\mathrm{NH}_{4} \mathrm{Cl}(100 \mathrm{~mL})$, followed by addition of water $(100 \mathrm{~mL})$. The aqueous layer was extracted with methylene chloride $(3 \times 100$ $\mathrm{mL})$, and combined organic layers were washed with water $(2 \times$ $100 \mathrm{~mL})$, and brine $(100 \mathrm{~mL})$. The organic phase was dried over anhydrous $\mathrm{MgSO}_{4}$ and concentrated under reduced pressure (below $35^{\circ} \mathrm{C}$ ). Crude product was purified by column chromatography Hex/EtOAc $(1: 0)$ to $(85: 15)$ to give the title compound as a mixture of diastereoisomers $(Z / E 1: 0.5)$ as almost colorless oil (5.75 g, $11.8 \mathrm{mmol}, 77 \%) .{ }^{1} \mathrm{H}$ NMR (600 $\left.\mathrm{MHz} \mathrm{CDCl}_{3}\right) \delta 9.73(\mathrm{~s}, 1 \mathrm{H}), 9.61(\mathrm{~d}, J=1.6 \mathrm{~Hz}, 0.5 \mathrm{H}), 7.34-7.26$ (m, 19.5H), 7.25-7.20 (m, 3H), 6.99 (dd, $J=15.8,6.7 \mathrm{~Hz}, 0.5 \mathrm{H})$, $6.28(\mathrm{dd}, J=11.7,8.7 \mathrm{~Hz}, 1 \mathrm{H}), 6.13(\mathrm{dd}, J=15.8,1.0 \mathrm{~Hz}, 0.5 \mathrm{H})$, $5.94(\mathrm{dd}, J=11.7,1.2 \mathrm{~Hz}, 1 \mathrm{H}), 5.49(\mathrm{dd}, J=8.7,3.5 \mathrm{~Hz}, 1 \mathrm{H})$, 4.69-4.45 (m, 7.5H), 4.41 (d, $J=11.8 \mathrm{~Hz}, 1 \mathrm{H}), 4.28-4.20(\mathrm{~m}$, $1.5 \mathrm{H}), 4.19-4.15(\mathrm{~m}, 2.5 \mathrm{H}), 4.07$ (dd, $J=3.5,1.6 \mathrm{~Hz}, 0.5 \mathrm{H}), 4.00-$ $3.97(\mathrm{~m}, 2 \mathrm{H}), 3.87(\mathrm{dd}, J=7.6,3.5 \mathrm{~Hz}, 0.5 \mathrm{H}), 1.31(\mathrm{t}, J=7.1 \mathrm{~Hz}$, $1.5 \mathrm{H}), 1.27$ (t, $J=7.1 \mathrm{~Hz}, 3 \mathrm{H}) ;{ }^{13} \mathrm{C} \mathrm{NMR}\left(150 \mathrm{MHz}, \mathrm{CDCl}_{3}\right.$ ) $\delta 202.7,201.3,165.9,165.9,147.2,145.2,138.0,137.9,137.3$, 137.1 , 137.0, 128.7, 128.6, 128.5, 128.5, 128.4, 128.4, 128.1, 128.1, 128.0, 128.0, 127.8, 127.7, 124.6, 122.5, 83.7, 83.3, 81.2, 74.6, 74.3, 73.6, 73.3, 73.2, 71.7, 71.3, 60.7, 60.5, 14.3, 14.3; HRMS (ESI): calcd for $\mathrm{C}_{30} \mathrm{H}_{22} \mathrm{O}_{6} \mathrm{Na}[\mathrm{M}+\mathrm{Na}]^{+} 511.2091$, found 511.2091.

\section{Ethyl 3,4,5-tri-O-benzyl-6-hydroxyshikimate (5)}

A suspension of elemental selenium (1.09 $\mathrm{g}, 13.75 \mathrm{mmol})$ in anhydrous THF $(250 \mathrm{~mL})$ was cooled in an ice bath and $n$-BuLi (1.6 $\mathrm{M}$ in hexanes, $8.6 \mathrm{~mL}, 13.75 \mathrm{mmol}$ ) was added dropwise (a clear solution was produced) and the mixture was stirred for $15 \mathrm{~min}$ in $0{ }^{\circ} \mathrm{C}$. After that reaction mixture was cooled to $-78^{\circ} \mathrm{C}$, solution of 8 (5.60 g, $11.46 \mathrm{mmol}$ in $100 \mathrm{~mL}$ of anhydrous THF) was added dropwise and stirring was continued through the next 30 min and then cryo-bath was removed and mixture was allowed to warm to room temperature and stirring was continued for the next $1 \mathrm{~h}$. After that time, reaction was cooled to $0{ }^{\circ} \mathrm{C}$ and hydrogen peroxide $(35 \% \mathrm{v} / \mathrm{v}, 10.1 \mathrm{~mL}, 114.6 \mathrm{mmol})$ and pyridine $(4.6 \mathrm{~mL}, 57.3 \mathrm{mmol})$ were added. Ice bath was removed and mixture was heated to $50{ }^{\circ} \mathrm{C}$ for $1 \mathrm{~h}$ (solution became clear and colorless). After solvent evaporation under reduced pressure oily residue was dissolved in ethyl acetate (200 $\mathrm{mL})$, washed twice with water $(2 \times 80 \mathrm{~mL})$ and brine $(100 \mathrm{~mL})$ and dried over anhydrous $\mathrm{MgSO}_{4}$. Solvent was evaporated under reduced pressure and crude product was purified by column chromatography (Hex/EtOAc $4: 1$ to $3: 1$ ) to give title product as colorless syrup $(4.22 \mathrm{~g}, 8.65 \mathrm{mmol}, 76 \%, 6 S$ (anti)/6R(syn) $1: 0.33) .1 \mathrm{~g}$ sample of 5 was separated by column chromatography (Hex/EtOAc $5: 1$ to $3: 1)$ to give $(6 S)-5(0.75 \mathrm{~g})$ and $(6 R)-5$ $(0.24 \mathrm{~g})$. Ethyl $(6 S)$-3,4,5-tri- $O$-benzyl-6-hydroxyshikimate $(\mathbf{6 S}-5)$ : $[\alpha]_{\mathrm{D}}^{20}=-73.1\left(\mathrm{c} 1.0, \mathrm{CHCl}_{3}\right) ;{ }^{1} \mathrm{H} \mathrm{NMR}\left(600 \mathrm{MHz}, \mathrm{CDCl}_{3}\right) \delta 7.39-$ $7.27(\mathrm{~m}, 13 \mathrm{H}), 7.24-7.21(\mathrm{~m}, 2 \mathrm{H}), 6.96(\mathrm{dd}, J=2.5,0.9 \mathrm{~Hz}, 1 \mathrm{H})$, $4.77(\mathrm{~d}, J=11.9 \mathrm{~Hz}, 1 \mathrm{H}), 4.67(\mathrm{dd}, J=11.9,6.3 \mathrm{~Hz}, 3 \mathrm{H}), 4.63(\mathrm{~d}, J$ $=11.9 \mathrm{~Hz}, 1 \mathrm{H}), 4.56(\mathrm{~d}, J=11.8 \mathrm{~Hz}, 1 \mathrm{H}), 4.50(\mathrm{dd}, J=9.4,2.8 \mathrm{~Hz}$, $1 \mathrm{H}), 4.38(\mathrm{t}, J=2.8 \mathrm{~Hz}, 1 \mathrm{H}), 4.29-4.22(\mathrm{~m}, 2 \mathrm{H}), 4.05(\mathrm{dd}, J=5.5$, $2.9 \mathrm{~Hz}, 1 \mathrm{H}), 3.94-3.91(\mathrm{~m}, 1 \mathrm{H}), 3.30(\mathrm{~d}, J=9.3 \mathrm{~Hz}, 1 \mathrm{H}), 1.31(\mathrm{t}, J$ $=7.1 \mathrm{~Hz}, 3 \mathrm{H}) ;{ }^{13} \mathrm{C} \mathrm{NMR}\left(150 \mathrm{MHz}, \mathrm{CDCl}_{3}\right) \delta 166.0,138.0,137.9$, 137.7, 137.4, 132.1, 128.6, 128.2, 128.1, 128.0, 127.8, 127.8, 77.4, 74.3, 73.7, 73.7, 72.8, 71.9, 66.2, 61.0, 14.3; HRMS (ESI): calcd for $\mathrm{C}_{30} \mathrm{H}_{32} \mathrm{O}_{6} \mathrm{Na}[\mathrm{M}+\mathrm{Na}]^{+}$511.2091, found 511.2091; Ethyl (6R)3,4,5-tri-O-benzyl-6-hydroxyshikimate $(6 \boldsymbol{R}-5):[\alpha]_{\mathrm{D}}^{20}=-82.9(\mathrm{c}$ 1.0, $\mathrm{CHCl}_{3}$ ); ${ }^{1} \mathrm{H}$ NMR (600 MHz, $\left.\mathrm{CDCl}_{3}\right) \delta 7.38-7.27(\mathrm{~m}, 15 \mathrm{H})$, $6.88(\mathrm{~d}, J=3.7 \mathrm{~Hz}, 1 \mathrm{H}), 4.80(\mathrm{t}, J=3.2 \mathrm{~Hz}, 1 \mathrm{H}), 4.76(\mathrm{~d}, J=$ 
$11.7 \mathrm{~Hz}, 1 \mathrm{H}), 4.73-4.66(\mathrm{~m}, 4 \mathrm{H}), 4.62(\mathrm{~d}, J=11.9 \mathrm{~Hz}, 1 \mathrm{H}), 4.30(\mathrm{t}$, $J=3.3 \mathrm{~Hz}, 1 \mathrm{H}), 4.23(\mathrm{qd}, J=7.1,1.0 \mathrm{~Hz}, 2 \mathrm{H}), 4.04(\mathrm{dd}, J=7.9$, $4.1 \mathrm{~Hz}, 1 \mathrm{H}), 3.94(\mathrm{dd}, J=7.9,3.7 \mathrm{~Hz}, 1 \mathrm{H}), 3.19$ (d, $J=3.3 \mathrm{~Hz}$, $1 \mathrm{H}), 1.29(\mathrm{t}, J=7.1 \mathrm{~Hz}, 3 \mathrm{H}) ;{ }^{13} \mathrm{C} \mathrm{NMR}\left(150 \mathrm{MHz}, \mathrm{CDCl}_{3}\right) \delta 166.3$, $138.4,138.2$, 137.9, 132.1, 128.6, 128.6, 128.5, 128.1, 128.0, 128.0, 127.8, 76.3, 75.5, 73.9, 73.4, 72.5 (2C), 65.4, 61.2, 14.3; HRMS (ESI): calcd for $\mathrm{C}_{30} \mathrm{H}_{32} \mathrm{O}_{6} \mathrm{Na}[\mathrm{M}+\mathrm{Na}]^{+} 511.2091$, found 511.2091.

\section{3,4,5-Tri-O-benzyl-(-)-MK7607 ((6R)-9)}

A solution of compound (6R)-5 $(0.10 \mathrm{~g}, 0.2 \mathrm{mmol})$ in anhydrous methylene chloride $(5 \mathrm{~mL})$ was cooled to $-30{ }^{\circ} \mathrm{C}$ and solution of DIBAL-H (1 M in methylene chloride, $1.2 \mathrm{~mL}, 1.2 \mathrm{mmol}$ ) was added dropwise. When the addition was complete, the mixture was stirred at $-10{ }^{\circ} \mathrm{C}$ for $3 \mathrm{~h}$. After that time, methanol $(1 \mathrm{~mL})$ was added to quench the reaction, and mixture was stirred at $-10{ }^{\circ} \mathrm{C}$ for $30 \mathrm{~min}$. After water addition ( $5 \mathrm{~mL}$ ) and few drops of $1 \mathrm{M}$ aqueous $\mathrm{HCl}$, water phase was extracted with methylene chloride $(3 \times 5$ $\mathrm{mL})$ and combined organic phases were washed with water $(2 \times 5$ $\mathrm{mL})$ and brine $(10 \mathrm{~mL})$ and dried over anhydrous $\mathrm{MgSO}_{4}$. Solvent was evaporated under reduced pressure. Crude oil was purified by column chromatography (Hex/EtOAc $2: 1$ to $1: 1$ ) to give title compound as a colorless syrup $(0.03 \mathrm{~g}, 0.067 \mathrm{mmol}, 33 \%) .[\alpha]_{\mathrm{D}}^{20}=$ -78.5 (c 1.1, $\left.\mathrm{CHCl}_{3}\right) ;{ }^{1} \mathrm{H}$ NMR (600 MHz, $\left.\mathrm{CDCl}_{3}\right) \delta$ 7.36-7.27 (m, $15 \mathrm{H}), 5.83(\mathrm{~d}, J=3.9 \mathrm{~Hz}, 1 \mathrm{H}), 4.75-4.68(\mathrm{~m}, 4 \mathrm{H}), 4.65(\mathrm{~d}, J=$ $11.5 \mathrm{~Hz}, 1 \mathrm{H}), 4.62$ (d, $J=12.1 \mathrm{~Hz}, 1 \mathrm{H}), 4.43(\mathrm{~s}, 1 \mathrm{H}), 4.24$ (d, $J=$ $13.4 \mathrm{~Hz}, 1 \mathrm{H}), 4.18-4.13(\mathrm{~m}, 2 \mathrm{H}), 4.02$ (dd, $J=8.2,4.3 \mathrm{~Hz}, 1 \mathrm{H}), 3.92$ (dd, $J=8.2,3.6 \mathrm{~Hz}, 1 \mathrm{H}), 2.83$ (d, $J=4.0 \mathrm{~Hz}, 1 \mathrm{H}) ;{ }^{13} \mathrm{C}$ NMR (150 $\left.\mathrm{MHz}, \mathrm{CDCl}_{3}\right) \delta 139.7,138.5,137.8,128.5,128.4,128.0,127.8,127.8$, 127.7, 123.8, 76.7, 75.6, 73.6, 73.2, 72.2, 72.0, 67.3, 64.9; HRMS (ESI): calcd for $\mathrm{C}_{28} \mathrm{H}_{30} \mathrm{O}_{5} \mathrm{Na}[\mathrm{M}+\mathrm{Na}]^{+}$469.1985, found 469.1987 .

\section{6-Epi-3,4,5-tri-O-benzyl-(-)-MK7607 ((6S)-9)}

A solution of compound (6S)-5 (0.22 g, $0.45 \mathrm{mmol})$ in anhydrous methylene chloride $(10 \mathrm{~mL})$ was cooled to $-30{ }^{\circ} \mathrm{C}$ and solution of DIBAL-H (1 M in methylene chloride, $2.7 \mathrm{~mL}, 2.7 \mathrm{mmol}$ ) was added dropwise. When the addition was complete, the mixture was stirred at $-10{ }^{\circ} \mathrm{C}$ for $3 \mathrm{~h}$. After that time, methanol $(2 \mathrm{~mL})$ was added to quench the reaction, and mixture was stirred at $-10{ }^{\circ} \mathrm{C}$ for $30 \mathrm{~min}$. After water addition $(10 \mathrm{~mL})$ and few drops $(0.5 \mathrm{~mL})$ of $1 \mathrm{M}$ aqueous $\mathrm{HCl}$, water phase was extracted with methylene chloride $(3 \times 10 \mathrm{~mL})$ and combined organic phases were washed with water $(2 \times 10 \mathrm{~mL})$ and brine. $(20 \mathrm{~mL})$ and dried over anhydrous $\mathrm{MgSO}_{4}$. Solvent was evaporated under reduced pressure. Crude oil was purified by column chromatography (Hex/EtOAc $2: 1$ to $1: 1$ ) to give title compound as a white solid (0.13 g, $0.29 \mathrm{mmol}, 65 \%)$. Mp. 82-83 ${ }^{\circ} \mathrm{C} ;[\alpha]_{\mathrm{D}}^{20}=$ -48.5 (c 0.65, $\mathrm{CHCl}_{3}$ ); ${ }^{1} \mathrm{H}$ NMR $\left(600 \mathrm{MHz}, \mathrm{CDCl}_{3}\right.$ ) $\delta$ 7.38-7.27 $(\mathrm{m}, 15 \mathrm{H}), 5.81(\mathrm{~d}, J=1.7 \mathrm{~Hz}, 1 \mathrm{H}), 4.76(\mathrm{~d}, J=11.9 \mathrm{~Hz}, 2 \mathrm{H}), 4.69-$ $4.65(\mathrm{~m}, 4 \mathrm{H}), 4.22$ (s, 3H), 4.11 (dd, $J=7.5,4.8 \mathrm{~Hz}, 1 \mathrm{H}), 3.98$ (dd, $J=7.2,4.7 \mathrm{~Hz}, 1 \mathrm{H}), 3.79(\mathrm{dd}, J=7.1,3.6 \mathrm{~Hz}, 1 \mathrm{H}), 2.87$ (d, $J=$ $8.0 \mathrm{~Hz}, 1 \mathrm{H}) ;{ }^{13} \mathrm{C} \mathrm{NMR}\left(150 \mathrm{MHz}, \mathrm{CDCl}_{3}\right) \delta 140.0,138.4,138.2$, $137.9,128.5,128.4,128.4,127.9,127.9,127.9$, 127.8, 127.7, 127.7, 122.4, 78.9, 76.5, 73.5, 73.1, 72.7, 71.7, 70.1, 64.5; HRMS (ESI): calcd for $\mathrm{C}_{28} \mathrm{H}_{30} \mathrm{O}_{5} \mathrm{Na}[\mathrm{M}+\mathrm{Na}]^{+} 469.1985$, found 469.1981 .

\section{6-Epi-3,4,5,6,7-penta-O-benzyl-(-)-MK7607 (10)}

To a stirred suspension of $\mathrm{NaH}(0.027 \mathrm{~g}, 0.67 \mathrm{mmol}, 60 \%$ in mineral oil) in anhydrous DMF ( $5 \mathrm{~mL})$ was added a solution of 9 $(0.130 \mathrm{~g}, 0.29 \mathrm{mmol})$ and $\mathrm{BnBr}(0.08 \mathrm{~mL}, 0.67 \mathrm{mmol})$ at $0{ }^{\circ} \mathrm{C}$ under argon. After $30 \mathrm{~min}$ of stirring, ice bath was removed and stirring was continued for $12 \mathrm{~h}$ in room temperature. The reaction mixture was carefully quenched with a cold, 10\% aqueous solution of $\mathrm{NH}_{4} \mathrm{Cl}(5 \mathrm{~mL})$. The aqueous layer was extracted with ethyl acetate $(3 \times 5 \mathrm{~mL})$. The organic layer was washed with $\mathrm{H}_{2} \mathrm{O}(5 \mathrm{~mL})$ and brine $(5 \mathrm{~mL})$, dried over anhydrous $\mathrm{MgSO}_{4}$, and concentrated under reduced pressure. The residue was purified by column chromatography (Hex/EtOAc $9: 1$ to $7: 1)$ to give title compound as a colorless syrup (0.117 g, $0.186 \mathrm{mmol}, 83 \%) \cdot[\alpha]_{\mathrm{D}}^{24}=-150.3$ (c 1.0, $\left.\mathrm{CHCl}_{3}\right) ;{ }^{1} \mathrm{H}$ NMR $(600$ $\left.\mathrm{MHz} \mathrm{CDCl}_{3}\right) \delta$ 7.41-7.27 (m, 25H), $5.92(\mathrm{~d}, J=5.3 \mathrm{~Hz}, 1 \mathrm{H}), 5.05$ $(\mathrm{d}, J=11.0 \mathrm{~Hz}, 1 \mathrm{H}), 4.85-4.66(\mathrm{~m}, 7 \mathrm{H}), 4.49(\mathrm{~d}, J=11.8 \mathrm{~Hz}, 1 \mathrm{H})$, $4.45(\mathrm{~d}, J=11.8 \mathrm{~Hz}, 1 \mathrm{H}), 4.32(\mathrm{dd}, J=10.0,7.1 \mathrm{~Hz}, 1 \mathrm{H}), 4.24-$ 4.17 (m, 2H), 4.12-4.08 (m, 1H), 3.96 (d, $J=12.5 \mathrm{~Hz}, 1 \mathrm{H}), 3.60$ $(\mathrm{dd}, J=10.1,3.5 \mathrm{~Hz}, 1 \mathrm{H}) ;{ }^{13} \mathrm{C} \mathrm{NMR}\left(150 \mathrm{MHz}, \mathrm{CDCl}_{3}\right) \delta 140.2$, 139.0, 138.9, 138.8, 138.6, 138.2, 128.5, 128.4, 128.4, 128.1, 128.0, 127.9, 127.8, 127.8, 127.7, 127.7, 127.6, 127.6, 123.5, 80.6, 80.0, 79.8, 75.0, 73.8, 72.7, 72.6, 71.8, 71.0, 70.4; HRMS (ESI): calcd for $\mathrm{C}_{42} \mathrm{H}_{42} \mathrm{O}_{5} \mathrm{Na}[\mathrm{M}+\mathrm{Na}]^{+}$649.2924, found 649.2927.

\section{4,5,6-Tri- $O$-benzyl-(-)-valienamine- $N$-benzyl carbamate (11)} and 4,5,6-tri- $O$-benzyl- $(+)-\beta$-valienamine- $N$-benzyl carbamate (12)

To a stirred solution of $\mathbf{1 0}(0.69 \mathrm{~g}, 0.11 \mathrm{mmol})$ in anhydrous toluene $(0.74 \mathrm{~mL})$ was added $\mathrm{Na}_{2} \mathrm{CO}_{3}(0.132 \mathrm{~g}, 1.25 \mathrm{mmol})$ and chlorosulfonyl isocyanate $(0.07 \mathrm{~mL}, 0.83 \mathrm{mmol})$ at $0{ }^{\circ} \mathrm{C}$ under argon. The reaction mixture was stirred for $15 \mathrm{~h}$ at $0{ }^{\circ} \mathrm{C}$ and quenched carefully with addition $\mathrm{H}_{2} \mathrm{O}(1 \mathrm{~mL})$. The aqueous layer was extracted with ethyl acetate $(2 \times 2 \mathrm{~mL})$. The organic layer was added to a solution of aqueous $25 \% \mathrm{Na}_{2} \mathrm{SO}_{3}(2 \mathrm{~mL})$. The reaction mixture was stirred for $24 \mathrm{~h}$ at room temperature. The organic layer was washed with $\mathrm{H}_{2} \mathrm{O}(\sim 3 \mathrm{~mL})$ and brine $(\sim 3$ $\mathrm{mL}$ ), dried over anhydrous $\mathrm{MgSO}_{4}$ and concentrated under reduced pressure. The solid residue was purified by column chromatography (Hex/EtOAc $7: 1$ to $4: 1$ ) to give title compounds 11 (0.038 g, $0.055 \mathrm{mmol}, 51 \%), 12$ (0.006 g, $0.01 \mathrm{mmol}, 9 \%)$ and substrate $10(0.013 \mathrm{~g}, 0.021 \mathrm{mmol}, 19 \%)$ was recovered. 4,5,6-Tri-O-benzyl-(-)-valienamine- $N$-benzyl carbamate (11): $[\alpha]_{\mathrm{D}}^{20}=-28.9\left(\mathrm{c} 1.0, \mathrm{CHCl}_{3}\right) .{ }^{1} \mathrm{H}$ NMR and ${ }^{13} \mathrm{C}$ NMR spectra are identical as reported in lit. for enantiomer; ${ }^{\mathbf{1 6}}$ ${ }^{1} \mathrm{H}$ NMR $\left(600 \mathrm{MHz}, \mathrm{CDCl}_{3}\right) \delta 7.38-7.27(\mathrm{~m}, 24 \mathrm{H}), 7.25(\mathrm{~s}, 1 \mathrm{H})$, $5.82(\mathrm{~s}, 1 \mathrm{H}), 5.15-5.05(\mathrm{~m}, 3 \mathrm{H}), 4.75(\mathrm{~d}, J=11.4 \mathrm{~Hz}, 1 \mathrm{H}), 4.72-$ $4.55(\mathrm{~m}, 6 \mathrm{H}), 4.48(\mathrm{~d}, J=11.8 \mathrm{~Hz}, 1 \mathrm{H}), 4.40(\mathrm{~d}, J=11.8 \mathrm{~Hz}, 1 \mathrm{H})$, $4.24(\mathrm{~d}, J=12.1 \mathrm{~Hz}, 1 \mathrm{H}), 4.06(\mathrm{~d}, J=3.4 \mathrm{~Hz}, 1 \mathrm{H}), 3.91$ (d, $J=$ $12.1 \mathrm{~Hz}, 1 \mathrm{H}), 3.81$ (dd, $J=7.4,4.8 \mathrm{~Hz}, 1 \mathrm{H}), 3.77-3.71(\mathrm{~m}, 1 \mathrm{H})$; ${ }^{13} \mathrm{C}$ NMR $\left(150 \mathrm{MHz}, \mathrm{CDCl}_{3}\right) \delta 156.2,138.3,138.2,137.9,137.2$, 136.6 , 128.6, 128.5, 128.5, 128.4, 128.2, 128.1, 128.0, 127.9, 127.7, 125.2, 76.3, 75.9, 74.4, 73.8, 72.2, 72.1, 70.6, 66.9, 47.2; HRMS (ESI): calcd for $\mathrm{C}_{43} \mathrm{H}_{43} \mathrm{NO}_{6} \mathrm{Na}[\mathrm{M}+\mathrm{Na}]^{+}$692.2983, found 692.2982. 4,5,6-Tri-O-benzyl-(+)- $\beta$-valienamine- $N$-benzyl carbamate (12): ${ }^{1} \mathrm{H}$ NMR and ${ }^{13} \mathrm{C}$ NMR spectra are identical as we previously reported; ${ }^{24}{ }^{1} \mathrm{H}$ NMR $\left(600 \mathrm{MHz}, \mathrm{CDCl}_{3}\right) \delta 7.35-7.26(\mathrm{~m}$, 
25H), $5.65(\mathrm{~s}, 1 \mathrm{H}), 5.13-5.06(\mathrm{~m}, 2 \mathrm{H}), 4.83-4.62(\mathrm{~m}, 7 \mathrm{H}), 4.47(\mathrm{~d}$, $J=11.8 \mathrm{~Hz}, 1 \mathrm{H}), 4.43(\mathrm{~d}, J=11.8 \mathrm{~Hz}, 1 \mathrm{H}), 4.21(\mathrm{~d}, J=8.0 \mathrm{~Hz}$, $2 \mathrm{H}), 3.88(\mathrm{~d}, J=12.3 \mathrm{~Hz}, 2 \mathrm{H}), 3.53(\mathrm{t}, J=7.7 \mathrm{~Hz}, 1 \mathrm{H}) ;{ }^{13} \mathrm{C}$ NMR $\left(150 \mathrm{MHz}, \mathrm{CDCl}_{3}\right) \delta 155.9,138.4,138.3,138.2,136.6,136.4$, $128.6,128.6,128.5,128.3,128.2$, 128.1, 128.0, 127.9, 127.9, $127.8,127.8,126.2,82.3,79.7,77.9,74.7,74.3,74.2,72.6,70.4$, $66.8,52.1$.

\section{3,4,5-Tri-O-benzyl-(-)-MK7607 and 6-epi-3,4,5-tri-O-benzyl- (-)-MK7607 - mixture of diastereoisomers (9)}

A solution of compound $5(0.30 \mathrm{~g}, 0.61 \mathrm{mmol})$ in anhydrous methylene chloride $(10 \mathrm{~mL})$ was cooled to $-30{ }^{\circ} \mathrm{C}$ and solution of DIBAL-H (1 M in methylene chloride, $3.7 \mathrm{~mL}, 3.7 \mathrm{mmol}$ ) was added dropwise. When the addition was complete, the mixture was stirred at $-10{ }^{\circ} \mathrm{C}$ for $3 \mathrm{~h}$. After that time, methanol $(2 \mathrm{~mL})$ was added to quench the reaction, and mixture was stirred at $-10{ }^{\circ} \mathrm{C}$ for $30 \mathrm{~min}$. After water addition $(10 \mathrm{~mL})$ and few drops $(<1 \mathrm{~mL})$ of $1 \mathrm{M}$ aqueous $\mathrm{HCl}$, water phase was extracted with methylene chloride $(3 \times 15 \mathrm{~mL})$ and combined organic phases were washed with water $(2 \times 15 \mathrm{~mL})$ and brine $(20 \mathrm{~mL})$ and dried over anhydrous $\mathrm{MgSO}_{4}$. Solvent was evaporated under reduced pressure. Crude oil was purified by column chromatography (Hex/EtOAc $2: 1$ to $1: 1$ ) to give title mixture of diastereoisomers as semi-solid residue $(0.131 \mathrm{~g}, 0.29 \mathrm{mmol}, 48 \%)$. Products were characterized as pure diastereoisomers (6S)-9 and (6R)-9.

\section{$(4 R, 5 R, 6 R / S)-4,5,6-T r i-O-b e n z y l-2-(($ tert-butyldiphenylsilyl)oxy) methyl)cyclohex-2-en-1-ol (13)}

A solution of mixture of compounds $9(0.120 \mathrm{~g}, 0.27 \mathrm{mmol})$ in anhydrous methylene chloride $(3 \mathrm{~mL})$ was cooled to $-20{ }^{\circ} \mathrm{C}$ and TBDPSCl ( $0.089 \mathrm{~g}, 0.32 \mathrm{mmol})$ was added in one portion followed by dropwise addition of solution of imidazole $(0.045 \mathrm{~g}$, $0.65 \mathrm{mmol}$ in $1 \mathrm{~mL}$ anhydrous DMF) and stirring was continued in $-20{ }^{\circ} \mathrm{C}$ for $30 \mathrm{~min}$. Ice bath was removed and mixture was allowed to warm to room temperature. After addition of water ( 5 $\mathrm{mL})$, product was extracted with EtOAc $(3 \times 10 \mathrm{~mL})$ and combined organic layers were washed with water $(2 \times 10 \mathrm{~mL})$, brine $(15 \mathrm{~mL})$ and dried over anhydrous $\mathrm{MgSO}_{4}$. After solvent evaporation, oily residue was purified by column chromatography (Hex/EtOAc $6: 1$ to $5: 1$ ) to give pure compound 13 (mixture of diastereoisomers) as a clear syrup $(0.118 \mathrm{~g}$, $0.17 \mathrm{mmol}, 64 \%) .{ }^{1} \mathrm{H}$ NMR $\left(600 \mathrm{MHz}, \mathrm{CDCl}_{3}\right) \delta 7.70-7.63(\mathrm{~m}$, $4.84 \mathrm{H}), 7.44-7.27(\mathrm{~m}, 25.41 \mathrm{H}), 5.96(\mathrm{~d}, J=4.5 \mathrm{~Hz}, 0.21 \mathrm{H}), 5.87$ $(\mathrm{d}, J=2.3 \mathrm{~Hz}, 1 \mathrm{H}), 4.82-4.63(\mathrm{~m}, 7.26 \mathrm{H}), 4.35-4.27(\mathrm{~m}, 2.42 \mathrm{H})$, $4.20(\mathrm{~d}, J=20.1 \mathrm{~Hz}, 1.21 \mathrm{H}), 4.16(\mathrm{t}, J=3.9 \mathrm{~Hz}, 0.21 \mathrm{H}), 4.07(\mathrm{~s}$, $1 \mathrm{H}), 4.04(\mathrm{dd}, J=9.0,4.2 \mathrm{~Hz}, 1 \mathrm{H}), 4.00(\mathrm{dd}, J=7.2,4.7 \mathrm{~Hz}, 1 \mathrm{H})$, $3.94(\mathrm{dd}, J=9.0,3.8 \mathrm{~Hz}, 0.21 \mathrm{H}), 3.77$ (dd, $J=7.2,3.7 \mathrm{~Hz}, 1 \mathrm{H})$, $2.69(\mathrm{~s}, 0.21 \mathrm{H}), 2.61(\mathrm{~d}, J=5.6 \mathrm{~Hz}, 1 \mathrm{H}), 1.08-1.05(\mathrm{~m}, 10.89 \mathrm{H})$; ${ }^{13} \mathrm{C}$ NMR $\left(150 \mathrm{MHz}, \mathrm{CDCl}_{3}\right) \delta 140.4,140.0,138.9,138.9,138.7$, $138.6,138.4,138.3,135.7,135.7,134.9,133.5,133.5,133.4$, $129.8,128.6$, 128.5, 128.5, 128.0, 127.9, 127.9, 127.8, 127.8, $127.7,127.7,127.6,121.8,120.8,79.4,77.0,76.3,73.6,73.2,73.1$, 72.6, 72.1, 72.0, 71.5, 69.6, 66.6, 64.8, 64.4, 27.0, 19.4; HRMS (ESI): calcd for $\mathrm{C}_{44} \mathrm{H}_{48} \mathrm{O}_{5} \mathrm{SiNa}[\mathrm{M}+\mathrm{Na}]^{+}$707.3163, found 707.3165 .

\section{3,4,5-Tri-O-benzyl-1-tert-butyldiphenylsilyl-(-)-gabosine E (14)}

A solution of compound $13(0.115 \mathrm{~g}, 0.17 \mathrm{mmol})$ in anhydrous methylene chloride ( $3 \mathrm{~mL}$ ) was cooled to $0{ }^{\circ} \mathrm{C}$ and Dess-Martin periodinane $(0.214 \mathrm{~g}, 0.50 \mathrm{mmol})$ was added in one portion and stirred in $0{ }^{\circ} \mathrm{C}$ for $30 \mathrm{~min}$. After that time ice bath was removed and reaction mixture was stirred for $2 \mathrm{~h}$ in room temperature. Reaction was quenched with $0.2 \mathrm{~mL}$ of saturated aqueous solution of $\mathrm{NaHCO}_{3}$ and evaporated to dryness with silica gel $(<0.5 \mathrm{~g})$. After column chromatography (Hex/EtOAc $7: 1$ to $6: 1$ ) pure product was obtained as a clear syrup $(0.108 \mathrm{~g}, 0.16 \mathrm{mmol}$, 94\%). $[\alpha]_{\mathrm{D}}^{23}=-187.5$ (c 1.0, $\mathrm{CHCl}_{3}$ ); ${ }^{1} \mathrm{H}$ NMR (600 MHz, $\mathrm{CDCl}_{3}$ ) $\delta 7.62$ (ddd, $J=10.4,8.0,1.3 \mathrm{~Hz}, 4 \mathrm{H}), 7.43-7.27(\mathrm{~m}, 21 \mathrm{H}), 7.04$ $(\mathrm{dd}, J=4.5,2.1 \mathrm{~Hz}, 1 \mathrm{H}), 4.86(\mathrm{~d}, J=11.4 \mathrm{~Hz}, 1 \mathrm{H}), 4.83-4.78(\mathrm{~m}$, $2 \mathrm{H}), 4.76-4.69(\mathrm{~m}, 2 \mathrm{H}), 4.65(\mathrm{~d}, J=11.4 \mathrm{~Hz}, 1 \mathrm{H}), 4.46-4.37(\mathrm{~m}$, $3 \mathrm{H}), 4.35$ (d, $J=8.2 \mathrm{~Hz}, 1 \mathrm{H}), 3.93(\mathrm{dd}, J=8.2,3.3 \mathrm{~Hz}, 1 \mathrm{H}), 1.08$ $(\mathrm{s}, 9 \mathrm{H}) ;{ }^{13} \mathrm{C}$ NMR $\left(150 \mathrm{MHz}, \mathrm{CDCl}_{3}\right) \delta 196.4,138.8,138.3,138.2$, 138.0, 135.6, 135.5, 133.2, 133.1, 129.9, 129.9, 128.6, 128.5, 128.4, 128.1, 128.0, 127.9, 127.9, 127.9, 80.4, 78.9, 74.1, 73.3, 72.6, 72.2, 60.5, 27.0, 19.4; HRMS (ESI): calcd for $\mathrm{C}_{44} \mathrm{H}_{46} \mathrm{O}_{5} \mathrm{SiNa}$ $[\mathrm{M}+\mathrm{Na}]^{+} 705.3007$, found 705.3007 .

\section{3,4,5-Tri-O-benzyl-(-)-gabosine E (15)}

A solution of compound $14(0.038 \mathrm{~g}, 0.056 \mathrm{mmol})$ in anhydrous THF ( $1 \mathrm{~mL}$ ) was cooled to $0{ }^{\circ} \mathrm{C}$ and excess of $\mathrm{HF} \cdot \mathrm{Py}(0.05 \mathrm{~mL})$ complex was added dropwise and ice bath was removed and stirring was continued for next $12 \mathrm{~h}$ in room temperature. After that time reaction was quenched with water $(2 \mathrm{~mL})$ and product was extracted with EtOAc $(3 \times 5 \mathrm{~mL})$. Combined organic layers were washed with water $(5 \mathrm{~mL})$, brine $(10 \mathrm{~mL})$ and dried over anhydrous $\mathrm{MgSO}_{4}$. Solvent was evaporated under reduced pressure. Crude product was purified by column chromatography (Hex/EtOAc $4: 1$ to $1: 1$ ) to afford title compound as a clear syrup $(0.022 \mathrm{~g}, 0.05 \mathrm{mmol}, 89 \%) .[\alpha]_{\mathrm{D}}^{21}=-120.5$ (c 1.0, $\left.\mathrm{CHCl}_{3}\right) ;{ }^{1} \mathrm{H} \mathrm{NMR}\left(600 \mathrm{MHz}, \mathrm{CDCl}_{3}\right) \delta 7.39-7.27(\mathrm{~m}, 15 \mathrm{H}), 6.80(\mathrm{~d}$, $J=4.2 \mathrm{~Hz}, 1 \mathrm{H}), 4.86(\mathrm{~d}, J=11.5 \mathrm{~Hz}, 1 \mathrm{H}), 4.78(\mathrm{dd}, J=12.0$, $9.2 \mathrm{~Hz}, 2 \mathrm{H}), 4.71-4.65(\mathrm{~m}, 3 \mathrm{H}), 4.45(\mathrm{t}, J=3.7 \mathrm{~Hz}, 1 \mathrm{H}), 4.35(\mathrm{dt}, J$ $=14.3,1.2 \mathrm{~Hz}, 1 \mathrm{H}), 4.32(\mathrm{~d}, J=7.7 \mathrm{~Hz}, 1 \mathrm{H}), 4.23(\mathrm{~d}, J=14.3 \mathrm{~Hz}$, $1 \mathrm{H}), 3.99$ (dd, $J=7.7,3.3 \mathrm{~Hz}, 1 \mathrm{H}) ;{ }^{13} \mathrm{C} \mathrm{NMR}\left(150 \mathrm{MHz}, \mathrm{CDCl}_{3}\right.$ ) $\delta$ 197.3, 140.9, 138.1, 138.0, 138.0, 137.7, 128.6, 128.5, 128.5, 128.1, 128.0, 128.0, 128.0, 127.9, 80.0, 78.5, 73.9, 73.4, 72.7, 72.5, 60.9; HRMS (ESI): calcd for $\mathrm{C}_{28} \mathrm{H}_{28} \mathrm{O}_{5} \mathrm{Na}[\mathrm{M}+\mathrm{Na}]^{+}$467.1829, found 467.1829 .

\section{Ethyl (-)-3,4,5-tri- $O$-benzylshikimate (18)}

A solution of compound $5(0.50 \mathrm{~g}, 1.02 \mathrm{mmol})$ in anhydrous methylene chloride $(15 \mathrm{~mL})$ was cooled to $-20{ }^{\circ} \mathrm{C}$ and methanesulfonyl chloride $(0.238 \mathrm{~mL}, 3.07 \mathrm{mmol})$ was added in one portion followed by dropwise addition of triethylamine $(0.427$ $\mathrm{mL}, 3.07 \mathrm{mmol}$ ). After $30 \mathrm{~min}$ cryo-bath was removed and reaction mixture was allowed to warm to room temperature. Methylene chloride was evaporated under reduced pressure (below $30{ }^{\circ} \mathrm{C}$ ) and crude yellow oil was purified by flash column chromatography (Hex/EtOAc $5: 1$ to $4: 1$ ) to afford mixture of methanesulfonyl derivatives (16) as a clear syrup (0.545 g, $0.96 \mathrm{mmol}, 95 \%)$. HRMS (ESI): calcd for $\mathrm{C}_{31} \mathrm{H}_{34} \mathrm{O}_{8} \mathrm{SNa}[\mathrm{M}+\mathrm{Na}]^{+}$ 
589.1867, found 589.1867. Compound 16 was dissolved in anhydrous acetone $(10 \mathrm{~mL})$ and cooled to $0{ }^{\circ} \mathrm{C}$ followed by addition of $\mathrm{NaI}(1.44 \mathrm{~g}, 9.61 \mathrm{mmol})$. Reaction was stirred for $15 \mathrm{~min}$ in $0{ }^{\circ} \mathrm{C}$ and then heated to $40{ }^{\circ} \mathrm{C}$ for $2 \mathrm{~h}$ (covered with aluminum foil to avoid light access). Solvent was evaporated under reduced pressure (below $35^{\circ} \mathrm{C}$ ). Crude semi-solid residue was purified by flash column chromatography (Hex/EtOAc $7: 1$ to $6: 1)$ to afford iodine intermediate (17) as a clear, colorless syrup (0.560 g, $0.94 \mathrm{mmol}, 97 \%)$. Crude mixture (17) was dissolved in ethanol $(10 \mathrm{~mL})$ and cooled to $0{ }^{\circ} \mathrm{C}$, followed by addition of sodium borohydride $(0.071 \mathrm{~g}, 1.88 \mathrm{mmol})$ and vigorously stirred in $0{ }^{\circ} \mathrm{C}$ for $2 \mathrm{~h}$ (conversion of substrate was monitored by TLC). Reaction was quenched with diluted acetic acid (acetic acid/water v/v $1: 10,5 \mathrm{~mL}$ ). Product was extracted with EtOAc $(3 \times 5 \mathrm{~mL})$. Combined organic layers were washed with water $(2 \times 5 \mathrm{~mL})$, brine $(10 \mathrm{~mL})$ and dried over anhydrous $\mathrm{MgSO}_{4}$. After solvent evaporation title compound was purified by column chromatography (Hex/EtOAc $7: 1$ to $6: 1$ ) to afford product as clear syrup (0.415 g, $0.88 \mathrm{mmol}$, 93\% including $15 \%$ inseparable impurities), total yield after 3 step $=73 \%$ of pure 18. Ethyl (-)-3,4,5-tri-O-benzylshikimate (18): ${ }^{1} \mathrm{H}$ NMR $(600$ $\left.\mathrm{MHz}, \mathrm{CDCl}_{3}\right) \delta$ 7.39-7.22 (m, 15H), $6.92(\mathrm{~d}, J=1.0 \mathrm{~Hz}, 1 \mathrm{H}), 4.75-$ $4.63(\mathrm{~m}, 4 \mathrm{H}), 4.59$ (d, $J=11.9 \mathrm{~Hz}, 1 \mathrm{H}), 4.51$ (d, $J=11.9 \mathrm{~Hz}, 1 \mathrm{H})$, 4.35 (s, 1H), 4.19 (qd, $J=7.1,1.4 \mathrm{~Hz}, 2 \mathrm{H}), 3.96(\mathrm{dd}, J=10.3$, $4.3 \mathrm{~Hz}, 1 \mathrm{H}), 3.83(\mathrm{dd}, J=6.1,3.7 \mathrm{~Hz}, 1 \mathrm{H}), 2.72(\mathrm{ddt}, J=18.5,4.5$, $2.2 \mathrm{~Hz}, 1 \mathrm{H}), 2.47-2.41(\mathrm{~m}, 1 \mathrm{H}), 1.28(\mathrm{t}, J=7.1 \mathrm{~Hz}, 3 \mathrm{H}) ;{ }^{13} \mathrm{C}$ NMR $\left(150 \mathrm{MHz}, \mathrm{CDCl}_{3}\right) \delta 166.6,138.6,138.4,136.1,129.6,128.5$, 128.4, 127.9, 127.9, 127.8, 127.7, 127.7, 75.2, 73.9, 73.3, 73.1, 71.8, 71.7, 60.7, 27.9, 14.3; HRMS (ESI): calcd for $\mathrm{C}_{30} \mathrm{H}_{32} \mathrm{O}_{5} \mathrm{Na}[\mathrm{M}$ $+\mathrm{Na}]^{+}$495.2142, found 495.2142.

\section{(-)-3,4,5-Tri-O-benzylshikimic acid (19)}

$18(0.40 \mathrm{~g}, 0.85 \mathrm{mmol})$ was dissolved in THF $(5 \mathrm{~mL})$ followed by addition of water $(5 \mathrm{~mL})$ and $1 \mathrm{M} \mathrm{NaOH}(1 \mathrm{~mL})$ and reaction was stirred for $48 \mathrm{~h}$ in room temperature. After that time reaction mixture was treated with $1 \mathrm{M} \mathrm{HCl}$ (to $\mathrm{pH}=2$ ) and product was extracted with $\mathrm{Et}_{2} \mathrm{O}(4 \times 5 \mathrm{~mL})$. Combined organic layers were washed with water $(10 \mathrm{~mL})$, brine $(10 \mathrm{~mL})$ and dried over anhydrous $\mathrm{MgSO}_{4}$. Solvent was evaporated in atmospheric pressure. Product was purified by column chromatography (PhMe/EtOH/EtOAc $5: 1: 1$ ) to afford title compound as a colorless syrup ( $0.376 \mathrm{~g}, 0.846$, quant., $88 \%$ NMR purity). ${ }^{1} \mathrm{H}$ NMR (600 MHz, $\left.\mathrm{CDCl}_{3}\right) \delta 7.40-7.20(\mathrm{~m}, 15 \mathrm{H}), 7.05(\mathrm{~s}, 1 \mathrm{H}), 4.76-$ $4.61(\mathrm{~m}, 4 \mathrm{H}), 4.57$ (d, $J=11.9 \mathrm{~Hz}, 1 \mathrm{H}), 4.49$ (d, $J=11.9 \mathrm{~Hz}, 1 \mathrm{H})$, 4.35 (s, 1H), 3.95 (dd, $J=9.9,4.3 \mathrm{~Hz}, 1 \mathrm{H}), 3.82$ (s, 1H), 2.73-2.67 $(\mathrm{m}, 1 \mathrm{H}), 2.48-2.40(\mathrm{~m}, 1 \mathrm{H}) ;{ }^{13} \mathrm{C} \mathrm{NMR}\left(150 \mathrm{MHz}, \mathrm{CDCl}_{3}\right) \delta 171.4$, $138.8,138.6,138.3,138.3,128.5$, 128.4, 127.9, 127.9, 127.8, 127.8, 127.7, 75.0, 73.8, 73.3, 73.1, 71.8, 71.7, 27.6; HRMS (ESI): calcd for $\mathrm{C}_{28} \mathrm{H}_{28} \mathrm{O}_{5} \mathrm{Na}[\mathrm{M}+\mathrm{Na}]^{+} 467.1829$, found 467.1829.

\section{(-)-Methyl shikimate (20)}

To a solution of $19(0.210 \mathrm{~g}, 0.47 \mathrm{mmol})$ in anhydrous methylene chloride $(6 \mathrm{~mL})$ cooled to $-78{ }^{\circ} \mathrm{C}$ boron trichloride $(1 \mathrm{M}$ in methylene chloride, $9.5 \mathrm{~mL}, 9.50 \mathrm{mmol}$ ) was added dropwise and stirring was continued for $12 \mathrm{~h}$. Reaction was quenched by addition of anhydrous methanol $(2 \mathrm{~mL})$ and intense stirring was continued in $-78{ }^{\circ} \mathrm{C}$ for $1 \mathrm{~h}$. After solvent evaporation under reduced pressure (with $2 \mathrm{M} \mathrm{NaOH}$ trap) water was added (10 $\mathrm{mL}$ ), organic impurities were removed by washing water phase with methylene chloride $(3 \times 5 \mathrm{~mL})$. Water layer was acidified with $1 \mathrm{M} \mathrm{HCl}$ (to $\mathrm{pH}=5$ ) and solvent was evaporated under reduced pressure. Title compound was crystallized from EtOAc as white solid (0.060 g, $0.186 \mathrm{mmol}, 67 \%) . \mathrm{Mp} \mathrm{113-114}{ }^{\circ} \mathrm{C}$; $[\alpha]_{\mathrm{D}}^{21}=-138.0(\mathrm{c} \mathrm{0.5}, \mathrm{MeOH}) ;{ }^{1} \mathrm{H} \mathrm{NMR}\left(600 \mathrm{MHz}, \mathrm{CD}_{3} \mathrm{OD}\right) \delta 6.80$ $(\mathrm{dq}, J=1.8,1.4 \mathrm{~Hz}, 1 \mathrm{H}), 4.40-4.37(\mathrm{~m}, 1 \mathrm{H}), 4.01(\mathrm{dt}, J=7.1$, $5.2 \mathrm{~Hz}, 1 \mathrm{H}), 3.76(\mathrm{~s}, 3 \mathrm{H}), 3.33(\mathrm{dd}, J=4.0,2.4 \mathrm{~Hz}, 1 \mathrm{H}), 2.71$ (ddt, $J=18.2,4.7,1.9 \mathrm{~Hz}, 1 \mathrm{H}), 2.22(\mathrm{ddt}, J=18.2,5.4,1.7 \mathrm{~Hz}, 1 \mathrm{H}) ;{ }^{13} \mathrm{C}$ NMR (150 MHz, $\left.\mathrm{CD}_{3} \mathrm{OD}\right) \delta 169.5,139.9,131.0,73.4,69.2,68.1$, 53.2, 32.3; ${ }^{1} \mathrm{H}$ NMR and ${ }^{13} \mathrm{C}$ NMR are identical as previously reported. $^{26}$

\section{Conflicts of interest}

There are no conflicts to declare.

\section{Acknowledgements}

Financial support from the Polish National Science Centre (Grant No. 2015/17/D/ST5/01334) is gratefully acknowledged. The research was carried out with the equipment purchased thanks to the financial support of the European Regional Development Fund in the framework of the Polish Innovation Economy Operational Program (contract no. POIG.02.01.00-12023/08).

\section{Notes and references}

1 G. E. Mccasland, S. Furuta and L. J. Durham, J. Org. Chem., 1968, 33, 2835-2841.

2 G. E. Mccasland, S. Furuta and L. J. Durham, J. Org. Chem., 1968, 33, 2841-2844.

3 O. Arjona, A. M. Gómez, J. C. López and J. Plumet, Chem. Rev., 2007, 107, 1919-2036.

4 S. Roscales and J. Plumet, Int. J. Carbohydr. Chem., 2016, 2016, 1-42.

5 W. Ren, R. Pengelly, M. Farren-Dai, S. Shamsi Kazem Abadi, V. Oehler, O. Akintola, J. Draper, M. Meanwell, S. Chakladar, K. Świderek, V. Moliner, R. Britton, T. M. Gloster and A. J. Bennet, Nat. Commun., 2018, 9, 1-12.

6 S. Shamsi Kazem Abadi, M. Tran, A. K. Yadav, P. J. P. Adabala, S. Chakladar and A. J. Bennet, J. Am. Chem. Soc., 2017, 139, 10625-10628.

7 N. Tateda, K. Ajisaka, M. Ishiguro and T. Miyazaki, Bioorg. Med. Chem., 2018, 1-23.

8 H. Yuasa, O. Hindsgaul and M. M. Palcic, J. Am. Chem. Soc., 1992, 114, 5891-5892.

9 S. H. Yu and S. K. Chung, Tetrahedron: Asymmetry, 2005, 16, 2729-2747.

10 T. K. M. Shing, W. L. Ng, J. Y. W. Chan and C. B. S. Lau, Angew. Chem., Int. Ed., 2013, 52, 8401-8405.

11 M. Li, Y. Li, K. A. Ludwik, Z. M. Sandusky, D. A. Lannigan and G. A. O'Doherty, Org. Lett., 2017, 19, 2410-2413. 
12 X. Yang, P. Yuan, F. Shui, Y. Zhou and X. Chen, Org. Biomol. Chem., DOI: 10.1039/c9ob00469f.

13 D. C. Babu, C. B. Rao, K. Venkatesham, J. J. P. Selvam and Y. Venkateswarlu, Carbohydr. Res., 2014, 388, 130-137.

14 J. P. Rao and B. V. Rao, Tetrahedron: Asymmetry, 2010, 21, 930-935.

15 C. Muniraju, J. P. Rao and B. V. Rao, Tetrahedron: Asymmetry, 2012, 23, 86-93.

16 Q. R. Li, S. I. Kim, S. J. Park, H. R. Yang, A. R. Baek, I. S. Kim and Y. H. Jung, Tetrahedron, 2013, 26, 10384-10390.

17 P. Yuan, X. Liu, X. Yang, Y. Zhang and X. Chen, J. Org. Chem., 2017, 82, 3692-3701.

18 P. Wen and D. Crich, Tetrahedron, 2018, 74, 5183-5191.

19 J. Sardinha, A. P. Rauter and M. Sollogoub, Tetrahedron Lett., 2008, 49, 5548-5550.
20 D. H. Mac, S. Chandrasekhar and R. Grée, Eur. J. Inorg. Chem., 2012, 5881-5895.

21 G. M. Whited, G. International, K. Way and S. S. Francisco, Tetrahedron: Asymmetry, 1996, 7, 691-698.

22 H. A. J. Carless and Y. Dove, Tetrahedron: Asymmetry, 1996, 7, 649-652.

23 I. S. Kim, O. P. Zee and Y. H. Jung, Org. Lett., 2006, 8, 41014104.

24 P. Banachowicz, J. Mlynarski and S. Buda, J. Org. Chem., 2018, 83, 11269-11277.

25 N. R. Candeias, B. Assoah and S. P. Simeonov, Chem. Rev., 2018, 118, 10458-10550.

26 L. Sánchez-Abella, S. Fernández, N. Armesto, M. Ferrero and V. Gotor, J. Org. Chem., 2006, 71, 5396-5399. 